V. Parant. O самозванной больвненной форм'”, называемой прежлевременвымъ слабоумемь. D'une prétendue entité morbide dite démence précnce (Annales médico-psychologiques, 1905, Mars-Avril.

Aвторъ горячо возстает' противъ увлеченія доктрвной 0 dementia praecox, учевіемъ ве обоснованвымь, которое, по мвйію автора, совершевно вапрасво пытается занять черезъчурь большое м'ьсто въ патологіи душевныхъ больвней.

Сущвость разсуждевій автора сводится къ сльдуюпему:

Безспорно супествують состоянія дупевной больвни, встрбчаютіяся главным образощ' у молодыхь субъектовт, и бистро ведущія к', слабоумію. 'Тагимъ состояніямт можно, если угодно, давать названіе ранвее слайоуміе (dem. précoce); можно было-бы съ таким же успухомь называть такія состознія быстрымь слабоуміемь (démence rapide).

Ничто пе догазываеть, что такого рода слабоуміе является первичным. В官ь бредовыя состоянія наблюдаемыя въ началь' бользви, могуть вести или къ позднему слабоуміг, вли кт пстикному и полному вызлоровленію. Эта разнида вт развитіи бользви гораздо скорђе доказываеть, что слабоуміе въ такпх'ь случаяхъ является вторичным'ь, и что бредовыя явлеgія нельзя считать только добавочнымь әлементомъ; нащротивъ они представдяють собою супественное и первичное проявлевіе больвзи.

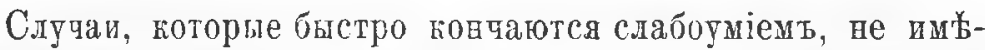
ютє, за исключеніемъ этой бшстроты въ развитіи јмственннаго упадка, ни общихъ характерныхъ свойствъ, ни отличительных'ь признаковъ, которые позволяли-бы разсматривать такіе случаи, каґъ однородную груицу, образующю самостоятельную клиническую форму.

Нов'ойшія концепціи, представляемыя поцъ именемъ преждевремевнаго слабоумія совершевно вскусстьенвы: ови повоятся лишь на бездогазательныхъ ув'ьредіяхь, которыя ве оправдываются ни сэміологическвми, ни патолого анатомическими данпши. Дидактическія описанія произвольно объединяють подъ этимь имевемъ веподходяція состоянія, везависящія одви отъ другихъ; они находятся в'є противорбчід ст данвыми кливическаго опыта, и, далево не имя прогрессив- 
ннаго значенія, напротивь склонны извращать пзученія психіатріи; онп ве им'ют' права занпмать въ пспхіатрической новографіи того мьста, которое претевдують препоставить имь.

\section{H. Tonoproвs.}

Artur $A$. D. Townsend. Психичеспое угнетеніе и меланхолія, разсмагриваемые съ точки зрывія аутоинтовсикаціи съ спепіальнымъ отqетом о присутствів индиксила въ мочь и кливическом значеніи этого авлепія. Mental Depression and Melancholic considered in regard to Auto-intoxication, with Special Reference to the presence of indoxyl in the Urine and its Clinical Significance. The Journal of mental Science, 1905, Ianuary.

Авторь въ теченіи двух'ь с'ь половиной левть изсльдовалт ва пндогсиль мочу во всехт сл!чаяхт остраго помьшательства, которые были подъ его наб.люденіемъ, исходя изъ соображенія, что излишнее воличество индоксила указываеть на ненормальные гвилостые процессы въ желудочно кишечном'ь тракть⿱⺊口).

Онъ излагаеть ревультаты 16 своихт наблюдевій, подавляющее большинство которнх'ь относится къ острой меланхоліи.

Въ 7 случалхъ изъ восьми выздоров ввшихъ уменьшеніе и исчезнөвеніе ивлишка индоксила пाло въ соотвйтствіи сь улучпеніем\% вт физическомь и психическомъ состояніи паціента. Во всьхъ случаях'ь излишен'ь ивдовсила изчез'ь, когда наступило выздоровлевіе.

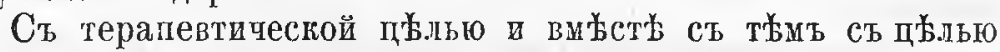
контролироват"ь вліяніе на гвилостные цроцессы въ кишеqникъ авторт првмьняль различныя дезивфедирующія средства: calomel, salol, naphtalin и пр., во все это безъ должваго результата.

Единственнымъ средствомъ, которое по наблюденіямъ автора уменьшаеть количество индогсила, являются тастыя слабительныя и исключительно молочная діэта. Но во многихь случаяхь трудно, и часто и невозможно заставить больных'ь подчиниться этому требованію.

Авторь па основаніи свопхъ пзсльддованіи прпходить кь сльедующвмт выводамъ: 